\title{
Antioxidation Activities of Organic Solvent Fractions Obtained from Seaweed, Hizikia fusiformis
}

\author{
Min-Jeong Kim ${ }^{1,2}$, Hye-Hyeon Lee ${ }^{1,2}$, Min-Jeong $\mathrm{SeO}^{2}$, Byoung-Won Kang ${ }^{2}$, Jeong Uck Park ${ }^{2}$ and \\ Yong Kee Jeong ${ }^{1,2} \star$
}

\author{
${ }^{1}$ Department of Biotechnology, Dong-A University, Busan 604-714, Korea \\ ${ }^{2}$ Medi-Farm Industrialization Research Center, Dong-A University, Busan 604-714, Korea
}

Received July 23, 2012 /Revised October 24, 2012 /Accepted December 20, 2012

\begin{abstract}
Hizikia fusiformis has been widely used in Oriental herbal medicine and health food. To identify antioxidation properties that contain natural bioactive substances, we investigated the distribution of active compounds existing in batches of organic solvent fractionation. A dried form of $H$. fusiformis was subjected to sequential fractionation using $n$-hexane, ethyl acetate, $n-\mathrm{BuOH}$, and aqueous $n$ - $\mathrm{BuOH}$. The results showed that among the four isolated fractions, the $n-\mathrm{BuOH}$ fraction showed the highest antioxidation activities. The $n-\mathrm{BuOH}$ fraction was applied to reserve-phase silica gel column chromatography, which produced three fractions: $\mathrm{BA}, \mathrm{BB}$, and $\mathrm{BC}$. Among these fractions, $\mathrm{BB}$ showed the highest antioxidation activities, which increased in a concentration-dependent manner. At a concentration of $1.0 \mathrm{mg} / \mathrm{ml} n-\mathrm{BuOH}$ fraction, the activities of DPPH (1,1-diphenyl-2-picrylhydrazyl) radical scavenging and reducing power were approximately $45 \pm 0.14 \%$ and $1.34 \pm 0.23$, respectively. In addition, the activities of $\beta$-carotene-linoleic acid, hydrogen peroxide scavenging, and ABTS (2,2'-azino-bis(3-ethylbenzothiazoline-6-sulphonic acid)) radical scavenging were $76 \pm 0.12 \%, 82 \pm 0.06 \%$, and $65 \pm 0.17 \%$, respectively. These findings suggest that the BB fraction contains potent antioxidation properties and that it could be used in the production of natural and functional foods.
\end{abstract}

Key words : Antioxidant activity, Hizikia fusiformis, 1,1-diphenyl-2-picrylhydrazyl (DPPH), 2,2'-azinobis(3-ethylbenzothiazoline-6-sulphonic acid) (ABTS)

\section{서 론}

최근 경제적 안정으로 인해 삶의 질이 높아짐에 따라 건강 한 삶에 관한 현대인들의 관심이 커지고 있다. 그러나 급격한 생활환경의 변화와 서구화된 식생활로 인해 발생되는 각종 노화, 암, 동맥경화증, 뇌질환과 심혈관질환, 신장질환 등에 의한 질병들이 사회적 문제로 제기되고 있다[5]. 이러한 질병 은 세포내 에너지대사 과정에서 생기는 superoxide anion, hydroxyl radical 및 peroxy radical과 같은 활성산소종(reactive oxygen species, ROS)에 의해서 세포내 단백질, 지질 및 DNA 가 기능적 손상을 받게 되어 생성된다[9]. 생체는 이러한 활성 산소부터 생체를 방어할 수 있는 superoxide dismutase (SOD), glutathione peroxidase (GPX), catalase (CAT), glutathione reductase, glutathione-S-transferase 등의 항산화 효소

\footnotetext{
*Corresponding author

Tel : +82-51-200-7557, Fax : +82-51-206-0848

E-mail : ykj9912@dau.ac.kr

This is an Open-Access article distributed under the terms of the Creative Commons Attribution Non-Commercial License (http://creativecommons.org/licenses/by-nc/3.0) which permits unrestricted non-commercial use, distribution, and reproduction in any medium, provided the original work is properly cited.
}

를 가지고 있으나[1], 과도한 스트레스에 노출되어 있는 현대 인에게는 더욱 효과적이고 안전한 대책이 필요하다. 이로 인 해 이에 대한 예방 및 개선책으로 안전성과 경제성을 고루 갖춘 천연물로부터 생리활성 물질들을 이용하려는 연구가 활 발히 진행되고 있다[6]. 이러한 천연물에 대한 연구는 대부분 육상생물에 한정되었으나, 그 희소성이 점차 고갈되어[14] 최 근에는 많은 잠재력을 가지고 있는 해양생물로 연구의 방향이 넓혀지고 있다. 그 중 해조류는 육상생물과는 다른 환경으로 생체 내 2차 대사산물의 화학구조가 매우 독특하며, 매우 중요 한 생리활성 물질들을 많이 함유하고 있어 그 연구가 활발히 진행되고 있다[10, 18, 19]. 해조류는 우리나라와 아시아 지역 에서 널리 분포되어 이용해 왔으며, 영양학적으로 소화 흡수 율이 낮아 큰 관심을 끌지 못했으나, 최근에 열량은 매우 낮고 비타민과 무기질, 식이섬유소가 풍부하며, 비소화성의 점질성 다당류를 다량 함유한다고 보고 되고 있다[13]. 또한 채소류에 비해서 필수 아미노산과 불포화지방산을 많이 함유하고 있다 [20].

본 연구에 사용된 톳(Hizikia fusiformis)은 갈조류 모자반과 의 다년생 해조류로서 우리나라에서는 주문진 이남에서 서해 안과 남해안 및 제주도에 걸쳐 서식한다. 다른 해조류에 비해 칼슘, 철, 요오드 같은 무기질, 비타민 등이 풍부하며, 항암[3], 면역증강[29], 항산화[31], 항균효과[23] 등에 관한 연구가 보고 
되고 있다. 특히 폴리페놀 화합물이 많은 분획 추출물에서 항 산화 효과가 컸다는 보고 $[8,25]$ 가 있었으나, 지속적인 연구는 미비한 상태이다. 현재 톳에서부터 분리된 항산화 물질들은 phlorotannin, 황산기를 갖는 다당류 등 한정된 연구에 그쳐 새로운 천연물질의 탐색이 필요한 상태이다[34, 35]. 따라서 본 연구에서는 해조류의 대표적인 톳의 $\mathrm{EtOH}$ 추출물을 용매 의 극성에 따라 분획하여 분리한 물질을 in vitro상태에서 다양 한 항산화 활성을 측정하여 비교, 검토하였다.

\section{재료 및 방법}

\section{시료}

본 실험에 사용된 톳(H fusiformis)은 2010년 3월 경상남도 거제에서 구입하여 실험 전 수세, 음건하여 실험 전까지 $-20^{\circ} \mathrm{C}$ 에서 냉동 보관하였다.

\section{톳 $\mathrm{EtOH}$ 추출 및 분획}

시료의 $\mathrm{EtOH}$ 추출물은 건조시료 10 배의 $80 \% \mathrm{EtOH}$ 을 가하 여 $4^{\circ} \mathrm{C}$ 에서 24 시간, 3 회 반복 추출하였다. 추출된 추출액은 여과(pore size $6 \mu \mathrm{m}$ ) 후 $40^{\circ} \mathrm{C}$ rotary vacuum evaporator (EYELA, Japan)로 농축 후 동결건조(BioTron, Hannil Co., Korea) 하였다. 추출된 $80 \%$ 톳 $\mathrm{EtOH}$ 추출물을 극성에 따라 용매별로 분획하여 Fig. 1 과 같이 분획물을 얻었다. 농축한 추 출물을 $n$ hexane, ethylacetate, $n-\mathrm{BuOH}$, aqueous $n-\mathrm{BuOH}$ 순 으로 각각 3회 연속 반복 추출한 다음 rotary vacuum evaporator로 유기용매를 증발시킨 후 동결 건조하여 사용하였다.

$n-\mathrm{BuOH}$ 분획물의 silica gel column chromatography $n-\mathrm{BuOH}$ 분획물을 RP-18 silica gel column chromatog-

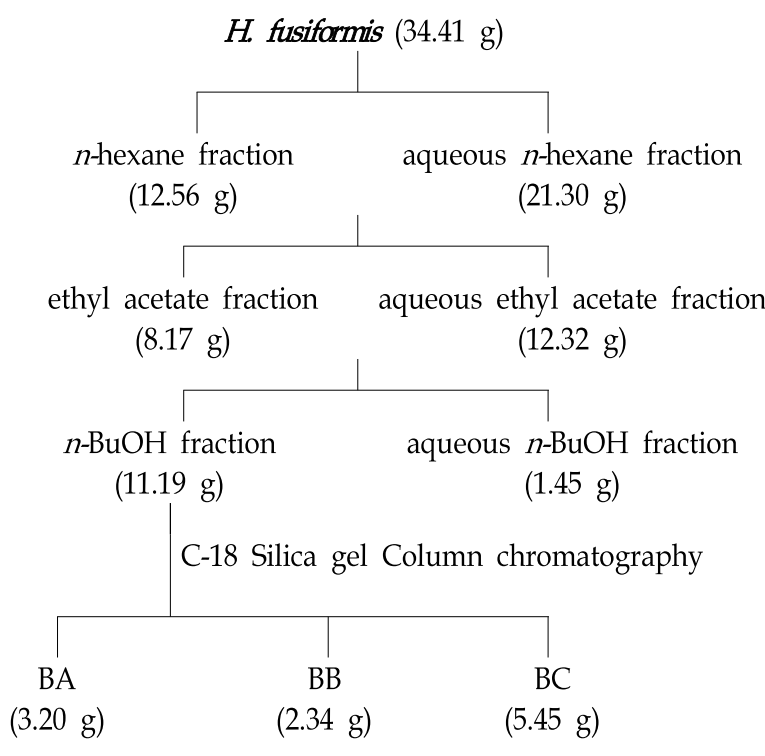

Fig. 1. Scheme of solvent fractionation of Hizikia fusiformis. raphy를 실시하였다. 전개용매는 $\mathrm{MeOH}:$ Water $=10: 1$ 로 용 출시키고 각각의 분획들은 $60 \mathrm{~F}_{254}$ plate TLC $(0.2 \mathrm{~mm}, 5 \times 7$ $\mathrm{cm}, \mathrm{Merck}$ 를 이용하여 유사한 pattern들을 합쳐 3 개의 분획 물을 얻었다.

Nuclear magnetic resonance spectrometry (NMR) 분석

AVANCE-500 (Bruker, Germany) NMR spectrometer에서 DMSO- $d_{b}$ 를 사용하여 ${ }^{1} \mathrm{H}-\mathrm{NMR}(500 \mathrm{MHz})$ 과 ${ }^{13} \mathrm{C}-\mathrm{NMR}(125$ $\mathrm{MHz}$ )를 얻었다.

\section{Free radical scavenging activity}

Free radical scavenging activity의 측정은 Brand-Williams method [2]을 이용하여 측정 하였다. $6 \times 10^{-5} \mathrm{M} \mathrm{DPPH}(1,1-\mathrm{di}-$ phenyl-2-picrylhydrazyl) 메탄올 용액 195 l와 메탄올로 희석 한 추출물 $5 \mu 1$ 를 96-microplate에 혼합하였다. 이때 혼합용액 중의 추출물 최종 농도는 $1.0 \mathrm{mg} / \mathrm{ml}$ 가 되도록 하였다. 실온에 서 30 분간 방치한 후 $515 \mathrm{~nm}$ 에서 흡광도를 측정하였고 기존의 항산화제로 알려진 BHA (butylated hydroxy anisole), BHT (butylated hydroxyl toluene), galic acid를 대조구로 사용하였 다. 시료의 항산화 효능은 시료 무첨가구에 대한 시료 첨가구 의 흡광도 비율로 산출하였다.

\section{Reducing power activity}

Reducing power activity의 측정은 Oyaizu method [30]을 이용하여 측정하였다. 시료 $50 \mu 1$ 에 $200 \mathrm{mM}$ phosphate-buffer (pH 6.6) $50 \mu 1$ 와 $1 \%$ potassium ferricyanide $50 \mu 1$ 를 넣고 $50^{\circ} \mathrm{C}$ 에서 20 분간 반응시켰다. 이때, 혼합용액 중의 추출물 최종 농도는 $1.0 \mathrm{mg} / \mathrm{ml}$ 가 되도록 하였다. 반응 종료 후 반응액에 $10 \%$ trichloroacetic acid 용액 $50 \mu 1$ 를 가하고 5,000 rpm에서 10 분간 원심분리 한 후 상등액 $100 \mu 1$ 취하여 증류수 $100 \mu 1$ 와 $1 \%$ ferric chloride $20 \mu 1$ 을 혼합한 후 10 분간 반응시킨 뒤 700 $\mathrm{nm}$ 에서 흡광도를 측정하였다.

\section{$\beta$-carotene-linoleic acid activity}

$\beta$-carotene-linoleic acid activity는 Miller method [26]을 이 용하여 측정하였다. $0.1 \mathrm{mg}$ 의 $\beta$-carotene을 chloroform 500 ul에 용해시킨 후 $20 \mathrm{mg}$ 의 linoleic acid 및 $100 \mathrm{mg}$ 의 Tween 40 을 첨가하여 $50^{\circ} \mathrm{C}$ 에서 chloroform을 감압 농축하여 제거하 고 얻어진 잔류물에 증류수 $50 \mathrm{ml}$ 를 가하여 정용한 것을 기질 액으로 사용하였다. 기질액 $10 \mu 1$ 와 시료 $200 \mu 1$ 를 96-microwell plate 가하여 혼합하였다. 이때 혼합용액 중의 추출물 최 종 농도는 $1.0 \mathrm{mg} / \mathrm{ml}$ 가 되도록 하였다. $50^{\circ} \mathrm{C}$ 에서 2 시간 반응 시킨 후 $470 \mathrm{~nm}$ 에서 흡광도를 측정하였으며, 시료의 항산화 효능은 시료 무 첨가구에 대한 시료 첨가구의 흡광도 비율로 산출하였다. 


\section{Hydrogen peroxide scavenging activity}

Hydrogen peroxide scavenging activity의 측정은 Miller method [26]을 이용하여 2,2-azinobis (3-ethylbenzthiazolin)6-sulfonicacid (ABTS)-peroxidase system에서 측정하였다. 96-microplate에 시료 $80 \mu \mathrm{l}, 10 \mathrm{mM} \mathrm{H} \mathrm{H}_{2} 20 \mu \mathrm{l}, 0.1 \mathrm{M}$ phosphatebuffer (pH 5.0) $100 \mu \mathrm{l}$ 를 넣고 혼합하였다. 이때, 혼합용 액 중의 추출물 최종 농도는 $1.0 \mathrm{mg} / \mathrm{ml}$ 가 되도록 하였고 $37^{\circ} \mathrm{C}$ 에서 5 분간 반응하였다. 반응액에 $1.25 \mathrm{mM} \mathrm{ABTS} 30 \mu \mathrm{l}$ 와 1 $\mathrm{U} / \mathrm{ml}$ peroxidase $30 \mu 1$ 를 가하고 혼합한 후 $37^{\circ} \mathrm{C}$ 에서 10 분간 반응하여 $405 \mathrm{~nm}$ 에서 흡광도를 측정하였으며, 시료의 항산화 효능은 시료 무첨가구에 대한 시료 첨가구의 흡광도비로 산출 하였다.

\section{ABTS radical scavenging activity}

ABTS radical scavenging activity ABTS radical 소거능 측 정은 $\mathrm{ABTS}^{+}$cation decolorization method [33]을 사용하였다. $7 \mathrm{mM}$ ABTS 용액에 potassium persulfate를 $2.4 \mathrm{mM}$ 이 되도록 용해시킨 다음 암실에서 12 시간 동안 반응 시켰다. 반응액의 흡광도를 $414 \mathrm{~nm}$ 에서 증류수로 희석하여 1.5 로 맞춘다. 희석 시킨 반응액 $3 \mathrm{ml}$ 에 시료용액 $1.0 \mathrm{ml}$ 를 가하여 실온에서 10 분 간 반응 시킨 다음 흡광도를 측정하였으며, 시료의 항산화 효 능은 시료 무첨가구에 대한 시료 첨가구의 흡광도비로 산출하 였다.

\section{통계분석}

본 실험에서 얻은 결과는 각 시료마다 세 번씩 반복 실험을 통해 실험군당 평균과 표준편차를 계산하여 나타내었다.

\section{결과 및 고찰}

\section{추출물 및 분획물}

건조 톳 시료 $(2 \mathrm{~kg})$ 를 $80 \%$ 에탄올로 추출한 후 여과하여 얻어진 추출액을 감압 농축하고 조추출물 $34.41 \mathrm{~g}$ 을 얻었다. 그리고 $80 \% \mathrm{EtOH}$ 추출물을 증류수로 현탁시킨 후에 $n$ hexane, ethylacetate, $n-\mathrm{BuOH}$ 등으로 순차적으로 분획하여 $n$-hexane 층에서 $12.56 \mathrm{~g}$, ethylacetate 층에서 $8.17 \mathrm{~g}, n \mathrm{BuOH}$ 층에서 $11.19 \mathrm{~g}$ 그리고 잔사인 $n-\mathrm{BuOH}$ 수용액 층에서 1.45 $\mathrm{g}$ 의 분획물을 얻었다. 각 순차적 분획물의 수율은 Table 1 에 나타내었으며, 추출에 사용한 톳의 $80 \% \mathrm{EtOH}$ 추출물의 수율 은 $58.12 \%$ 이었다. $\mathrm{EtOH}$ 추출물에 대한 각 순차적 분획물들을 항산화 활성 실험을 통해 가장 활성이 높은 $n \mathrm{BuOH}$ 층(11.19 g)을 RP-18 silica gel column chromatography를 실시하여 3 개의 분획물을 얻었다. 전개용매는 $\mathrm{MeOH}:$ water $=10: 1$ 로 용출시키고 각각의 분획들은 TLC로 전개하여 유사한 pattern 들을 합쳐 3 개의 분획물을 얻었다. 분획물 $\mathrm{BA} 3.20 \mathrm{~g}$, BB 2.34 $\mathrm{g}$ 그리고 $\mathrm{BC}$ 에서 가장 많은 $5.45 \mathrm{~g}$ 을 얻었다.
Table 1. Yields (\%) of each fractions from $80 \%$ ethanol extract of Hizikia fusiformis

\begin{tabular}{ccc}
\hline Fractions & Yields $(\mathrm{g})$ & Yields $(\%)$ \\
\hline 80\% EtOH ex. & 34.41 & 58.12 \\
$n$-hexane fr. & 12.56 & 36.50 \\
ethyl acetate fr. & 8.17 & 23.74 \\
$n$ - $\mathrm{BuOH}$ fr. & 11.19 & 32.51 \\
aqueous $n$ - $\mathrm{BuOH}$ fr. & 1.45 & 4.21 \\
BA fr. & 3.20 & 28.59 \\
BB fr. & 2.34 & 20.91 \\
BC fr. & 5.45 & 48.70 \\
\hline
\end{tabular}

*ex: extract, fr: fraction

Free radical scavenging activity

톳 $80 \% \mathrm{EtOH}$ 추출물 및 순차적 분획물의 Free radical 소거 능에 대한 결과와 $n \mathrm{BuOH}$ 층에서 분리된 3 개의 분획물에 대 한 농도별 소거능을 Fig. 2에 나타내었다. 추출물의 분리의 기

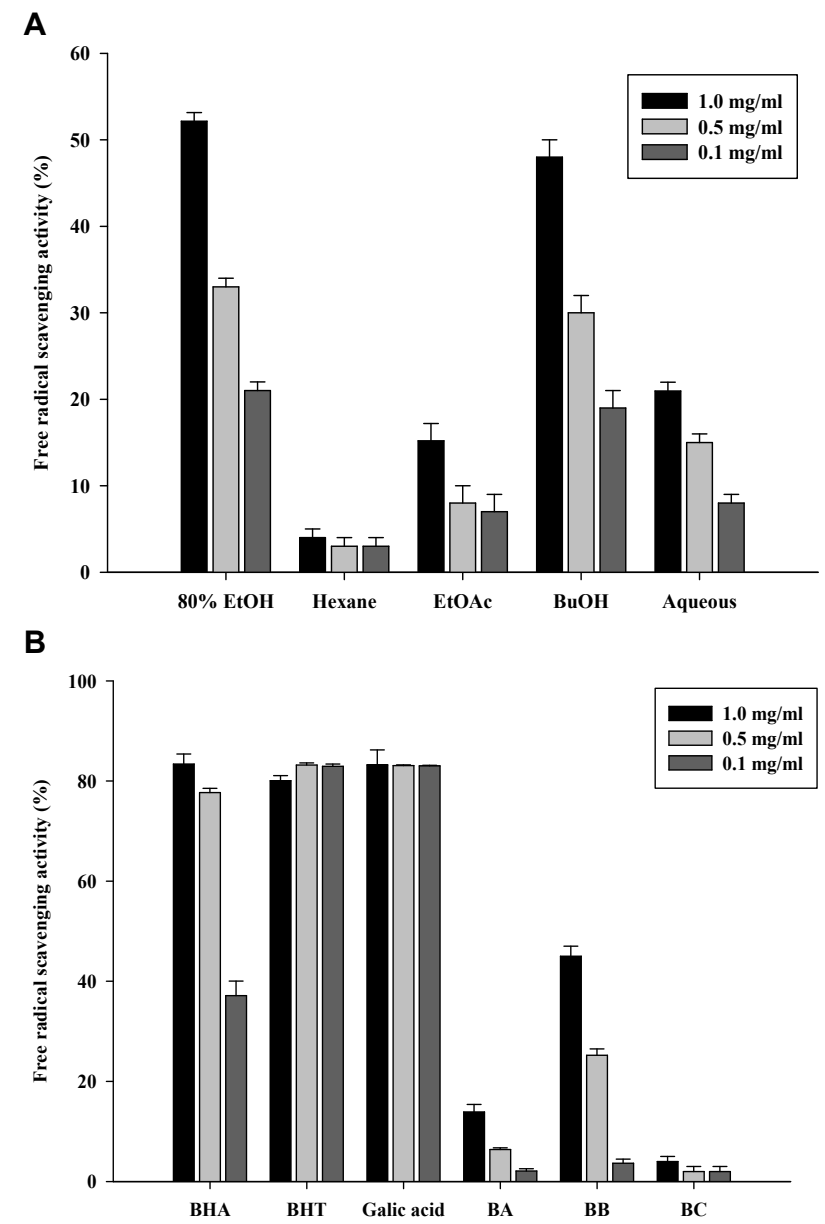

Fig. 2. Free-radical scavenging activity. (A) Various solvent fractions of $80 \% \mathrm{EtOH}$ extract from Hizikia fusiformis. (B) Isolated compounds from the $\mathrm{n}-\mathrm{BuOH}$ extract. $\mathrm{BHA}$ : butylated hydroxy ani-sole, BHT: butylated hydroxy toluene. 
준이 되는 free radical 소거능을 알아보기 위해 $1.0 \mathrm{mg} / \mathrm{ml}$ 의 농도에서 항산화능을 측정한 결과 $n-\mathrm{BuOH}>$ aqueous $n-\mathrm{BuOH}>$ ethylacetate $>n$-hexane 순으로 나타났다. 그 중 가장 높은 소거능을 나타내는 $n \mathrm{BuOH}$ 층에서 분리된 3 개의 분획물을 농도별로 항산화능을 확인하였다. 그 중 $\mathrm{BB}$ 분획물 이 농도가 $1.0 \mathrm{mg} / \mathrm{ml}$ 일 때 $45 \pm 0.14 \%$ 로 가장 높게 나타났으며, $\mathrm{BA}$ 분획물 보다는 3 배 높은 소거능을 나타낸다. $\mathrm{BC}$ 분획물에 서는 수율은 가장 높았으나 소거능은 거의 나타나지 않았다. 톳 $80 \% \mathrm{EtOH}$ 추출물의 free radical 소거능은 Karawita와 Park $[16,32]$ 에 보고되어 있다. 이는 본 실험에서 얻은 항산화 활성에 대한 결과보다 약간 높은 수치로 ethylacetate 분획물 에서 높은 항산화 물질이 존재하는데, 항산화 활성의 차이는 추출 방법과 추출시기, 부위에 따라 것으로 사료된다. 본 실험 을 통해 가장 높은 소거능을 보이는 BB 분획물은 식품의 산화 를 억제하며 $[11,21]$, 생체에서는 활성 radical에 의한 세포 손 상과 노화를 억제 하는 새로운 항산화제 소재로 충분히 활용 할 만한 가치를 지닌 기능성 물질로 예상된다[22].

\section{Reducing power activity}

활성 산소종 및 유리기에 전자를 공여하는 능력인 환원력은 항산화능과 밀접한 관련이 있는 것으로 알려져 있는데 이는 항산화 활성에 주요한 인자로 작용한다[7]. $700 \mathrm{~nm}$ 에서 ferricferricyanide $\left(\mathrm{Fe}^{3+}\right)$ 혼합물이 수소를 공여하여 radical을 안정화시켜 ferrous $\left(\mathrm{Fe}^{2+}\right)$ 로 전환하는 값을 나타낸 것인데 일 반적으로 환원력이 큰 것일수록 전자공여능이 높다고 알려져 있고, 전자공여능은 phenol성 물질에 대한 항산화 효능의 지 표라고 할 수 있다[17, 24]. 톳에서 분리된 3개의 분획물에 대한 환원력을 Fig. 3에 나타내었다. 분획물의 농도가 높아질수록 환원력은 증가하였으며, $1.0 \mathrm{mg} / \mathrm{ml}$ 의 농도에서 $\mathrm{BB}$ 분획물이 $1.34 \pm 0.23$ 로 가장 높은 환원력을 나타내었다. 이는 대조구로 사용된 BHA와 BHT 보다 높은 환원력을 나타내며, galic acid

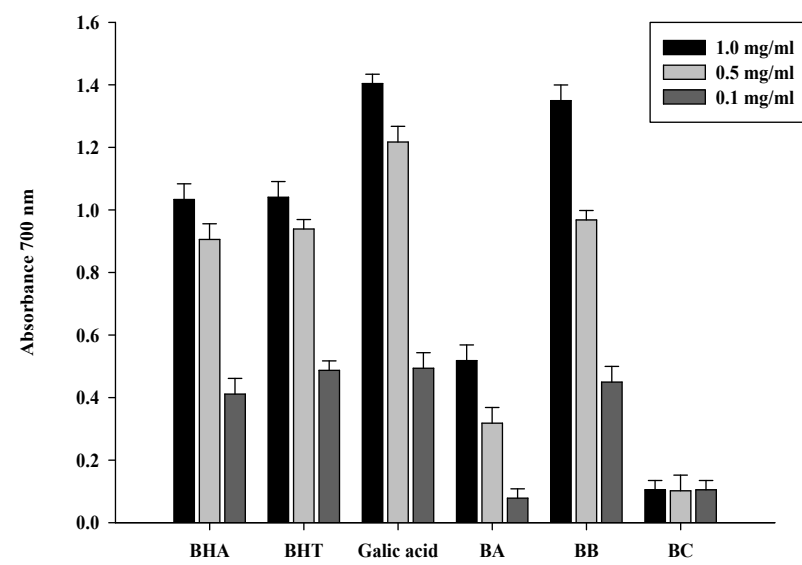

Fig. 3. Redcing power activity of isolated $\mathrm{n}-\mathrm{BuOH}$ extract from Hizikia fusiformis. BHA: butylated hydroxy ani-sole, BHT: butylated hydroxy toluene.
와 거의 유사한 활성을 나타낸다. 또한 BA 분획물에 비해서는 2 배 높은 활성을 나타내며, $\mathrm{BC}$ 분획물의 경우에는 특유의 짙 은 색에 의한 흡광도만 나타낼 뿐 환원력은 거의 없는 것으로 사료된다. $\mathrm{BB}$ 분획물은 다른 분획물들에 비해 환원력이 우수 하며, 시료의 농도가 증가할수록 환원력도 증가하였다.

\section{$\beta$-carotene-linoleic acid activity}

분획물의 지질과산화 억제능은 지질 산화 유도를 통해 생겨 난 free peroxyl radicals이 $\beta$-carotene의 이중결합을 공격함으 로서 원래의 오렌지색으로부터 빠르게 decolorization이 진행 되는 것을 $470 \mathrm{~nm}$ 에서 흡광도를 측정하였다[4]. 분획물들의 지질과산화 억제능은 Fig. 4 에 나타내었다. 그 중 가장 높은 활성을 보이는 BB 분획물은 대조구인 BHA와 BHT가 $1.0 \mathrm{mg} /$ 의 농도에서 $94 \%$ 와 $91 \%$ 의 높은 활성에 비해 다소 떨어지나 galic acid와는 $76 \pm 0.12 \%$ 의 유사한 활성을 보인다. 모든 시료 들이 농도에 따라 그 활성이 유의적인 것을 확인 할 수 있다. 특히 $\mathrm{BB}$ 분획물은 같이 분획된 $\mathrm{BA}$ 와 $\mathrm{BC}$ 분획물에 비해 2 배 이상의 높은 활성을 가진다. 지질과산화 억제능이 가장 우수 한 $\mathrm{BB}$ 분획물은 생체 내에서 $\mathrm{Fe}$ 과 같은 금속류가 과산화수소 와 빠르게 반응하여 생성되는 2 차 산화물의 생성을 억제하여 생체 내 손상을 방지할 것으로 예상된다.

\section{Hydrogen peroxide scavenging activity}

톳 분획물의 hydrogen peroxide $\left(\mathrm{H}_{2} \mathrm{O}_{2}\right)$ 소거활성을 측정한 결과는 Fig. 5 에 나타내었다. Hydrogen peroxide는 체내에서 세포 독성물질로 전이 금속이온과 함께 활성산소 종을 생산하 며, 체내에 생산되는 항산화 효소들에 의해 물로 전환되어 분 해된다[28]. Hydrogen peroxide 소거활성은 시료의 농도에 따

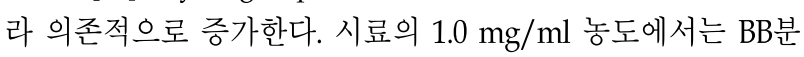
획물이 $82 \pm 0.06 \%$ 로 가장 높았으며, BA분획물에 비해서는 2 배, $\mathrm{BC}$ 분획물에 비해서는 4 배 가량 높은 소거능을 나타낸다.

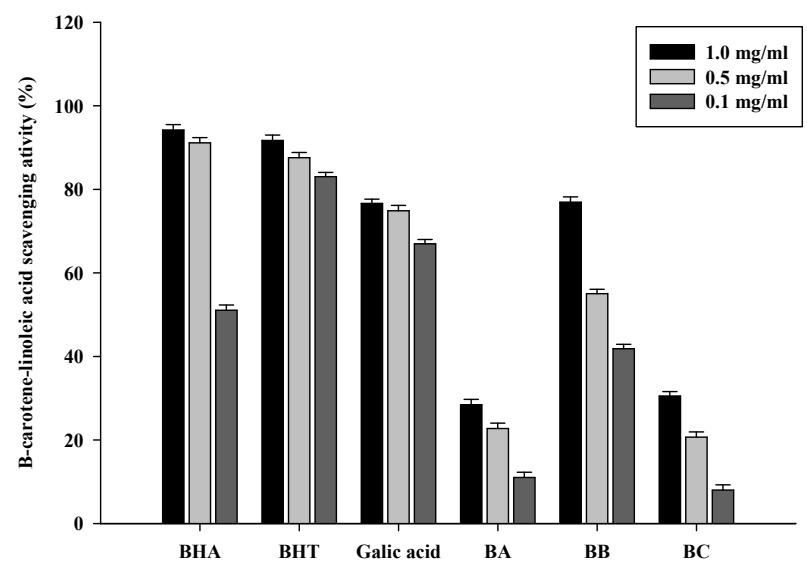

Fig. 4. $\beta$-carotene-linoleic acid activity of isolated n-BuOH extract from Hizikia fusiformis. BHA: butylated hydroxy ani-sole, BHT: butylated hydroxy toluene. 


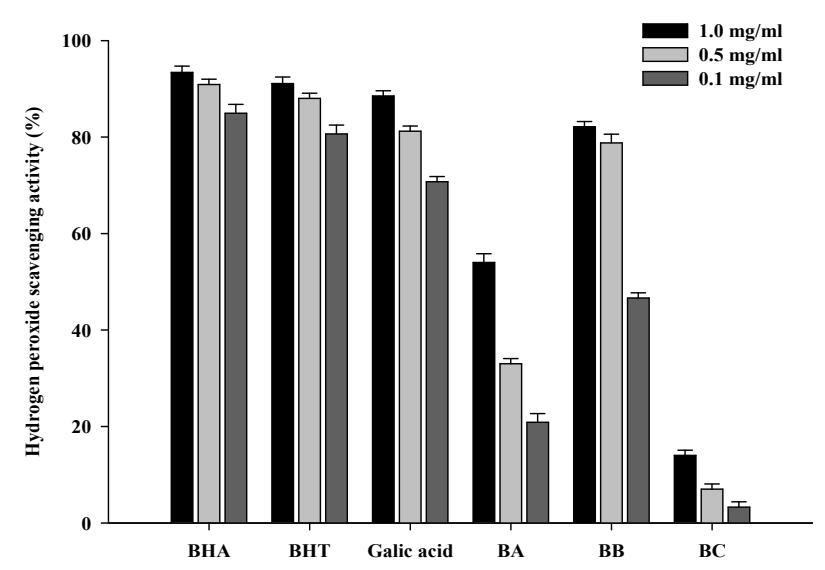

Fig. 5. Hydrogen peroxide scavenging activity of isolated $\mathrm{n}-\mathrm{BuOH}$ extract from Hizikia fusiformis. BHA: butylated hydroxy ani-sole, BHT: butylated hydroxy toluene.

특히 높은 농도에서는 대조구들과 비슷한 소거능을 나타내나, 농도가 낮아짐에 따라서 급격한 차이가 나는 것을 볼 수 있다.

\section{ABTS radical scavenging activity}

톳 분획물의 ABTS radical 소거능의 소거활성을 측정한 결 과는 Fig. 6에 나타내었다. ABTs 소거능은 postsium persulfate와 반응하여 생성된 ABTS radical이 시료중의 항산화 물질 에 의해 제거되어 radical 특유의 청록색이 탈색되는 정도를 $414 \mathrm{~nm}$ 에서 흡광도를 측정하였다[12]. 그 결과 시료 1.0 $\mathrm{mg} / \mathrm{ml}$ 의 농도에서 $\mathrm{BB}$ 분획물이 $65 \pm 0.17 \%$ 로 가장 높은 소거 능을 나타내었으며, 같이 분리된 BA 분획물에 비해서 2 배 높 은 소거능을 보이며, $\mathrm{BC}$ 분획물의 경우는 6 배 높은 소거능의 차이가 나타난다. 특히, 대조구들과 같이 농도가 높아질수록 소거능은 증가하였으며, galic acid와 비교할 때 농도의 변화에 따라 거의 유사한 소거능을 나타내었다. ABTS법에 의한 항산

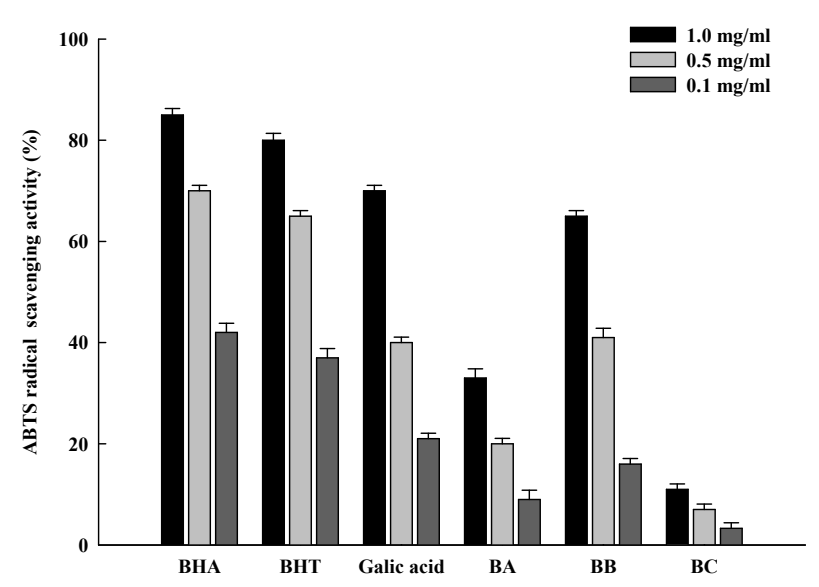

Fig. 6. ABTS radical scavenging activity of isolated n-BuOH extract from Hizikia fusiformis. BHA: butylated hydroxy ani-sole, BHT: butylated hydroxy toluene.
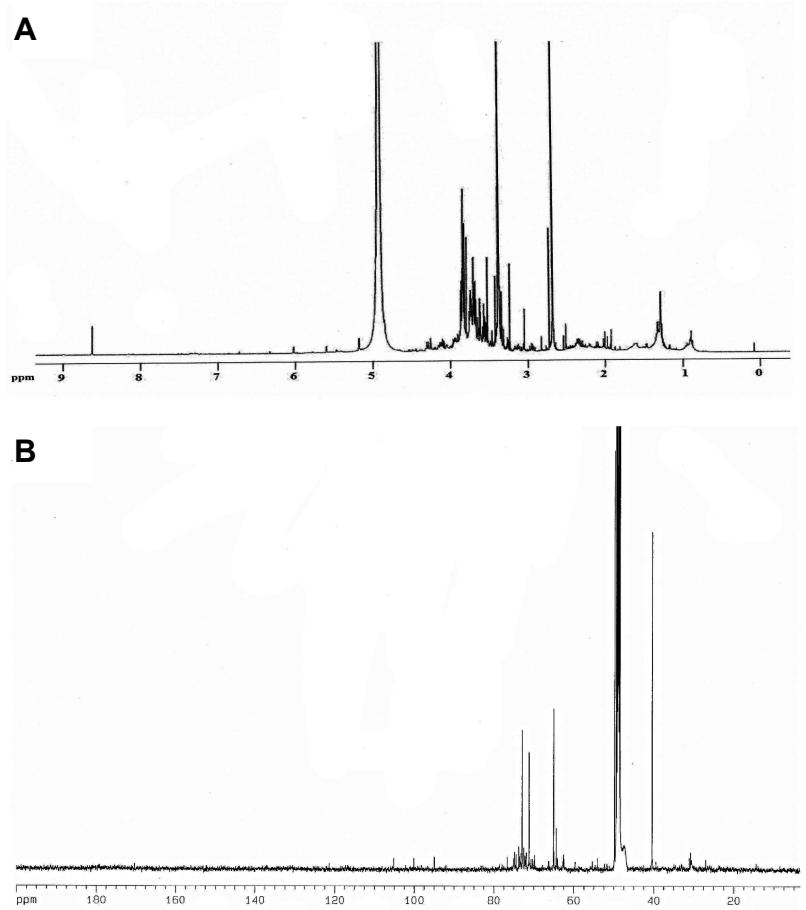

Fig. 7. $500 \mathrm{MHz}{ }^{1} \mathrm{H}-\mathrm{NMR}(\mathrm{A})$ and $125 \mathrm{MHz}{ }^{13} \mathrm{C}-\mathrm{NMR}$ (B) spectrum of $\mathrm{BB}$ fracion.

화력 측정법은 $\mathrm{DPPH}$ 는 free radical을 $\mathrm{ABTS}$ 는 양이온 radical 을 소거하는 점에서 서로 차이가 나며 두 기질과 반응물과의 결합 정도가 달라지므로 radical 제거 능력에서도 차이를 보이 나 $\mathrm{BB}$ 분획물은 모든 radical에서 우수한 소거능을 보였다.

이상의 결과에서 톳에서부터 분획된 용매 분획물 중 항산화 활성이 높은 $n \mathrm{BuOH}$ 에서 분리된 $\mathrm{BA}, \mathrm{BB}, \mathrm{BC}$ 의 항산화 활성 을 검토하였다. 그 중 가장 우수한 항산화능을 가진 물질을 함유하고 있을 것으로 사료되는 $\mathrm{BB}$ 분획물은 ${ }^{1} \mathrm{H}$ 과 ${ }^{13} \mathrm{C}-\mathrm{NMR}$ 을 측정하여 부분 정제된 분획물의 구조를 추정한 결과, 플라 본을 골격구조를 지니고 있는 화합물인 것으로 나타났다[15, 27]. ${ }^{1} \mathrm{H}-\mathrm{NMR}$ 스펙트럼에서는 7.0 8.0 ppm에서 플라본의 방 향족 화합물에 기인하는 수소가 관측되었으며 $3.5 ~ 4.3 \mathrm{ppm}$ 에 서는 다중 메톡시기에 속해 있는 수소가 관측되었다(Fig. 7A). 또한, ${ }^{13} \mathrm{C}-\mathrm{NMR}$ 스펙트럼에서는 $50 \sim 120 \mathrm{ppm}$ 에서 플라본의 방향족 화합물에 기인하는 탄소가 관측되었다(Fig. 7B). 이 결 과로부터 $\mathrm{BB}$ 분획물은 플라본의 골격구조에 메톡시기가 다중 결합된 구조를 하고 있는 물질로 추정되며 현재 $\mathrm{BB}$ 분획물의 완전 정제를 진행하고 있다. 또한 이를 기능성물질로 활용하 기 위하여 다양한 생리활성 평가가 필요할 것으로 생각된다.

\section{감사의 글}

본 연구는 농림수산식품부(농림, 식품, 수산) 기술개발사업 (610003-03-1-SB110)의 연구비지원에 의해서 수행되었습니다. 


\section{References}

1. Anderson, D. 1999. Antioxidant defences against reactive oxygen spicies causing genetic and other damage. Mutation Res 350, 103-108.

2. Brand-Williams, W., Cuvelier, M. E. and Berset, C. 1995. Use of a free radical method to evaluate antioxidant activity. Food Sci Technol 28, 25-30.

3. Cho, K. J., Lee, Y. S. and Ryu, B. H. 1990. Antitumor effect and immunology activity of seaweeds toward sarcoma-180. $J$ Korean Fish Soc 23, 345-352.

4. Choi, S. I., Lee, Y. M. and Hoo, T. R. 2003. Screening of hyaluronidase inhibitory and free radical scavenging activity in vitro of traditional herbal medicine extracts. Koean $J$ Biotech Bioeng 18, 282-288.

5. Cutler, R. G. Antioxidants aging, and longevity. 1984. Free Radicals in Biology. pp. 371-423, 6th eds., In Pryor, W. A. (ed), Academic press.

6. Gomes, A., Vedasiromoni, J. R., Das, M., Sharma, R. M. and Ganguly, D. K. 1995. Anti-hyperglycemic effect of black tea (Camellia sinensis) in rat. J Ethnopharmacol 45, 223-226.

7. Gordon, M. H. 1990. The mechanism of antioxidant action in vitro. In Food Antioxidant. pp. 1-18, In Hudson, B. J. F. (ed.), Elsevier Applied Science, London/New York.

8. Haung, H. L. and Wang, B. G. 2004. Antioxidant capacity and lipophilic content of seaweeds collected from the Qungdao coastline. J Agric Food Chem 52, 4993-4997.

9. Hur, S. K., Kim, S. S., Heo, Y. H., Ahn, S. M., Lee, B. G. and Lee, S. K. 2001. Effect of the grapevine shoot extracton free radical scavenger activity and inhibition of pro-inflammatory mediator production in raw macrophages. $J$ Appl Pharmacol 9, 188-193.

10. Jeon, M. H. and Kim, M. 2011. Effect of Hijikia fusiforme fractions on proliferation and differentiation in osteoblastic MC3T3-E1 Cells. J Life Sci 21, 300-308.

11. Jeong, D. S., Sohn, Y. K., Lee, Y. I., Yun, I. H. and Kim, J. K. 1986. Study on the chemical constituents and processings of Ganoderma lucidum Ann Res Report 28, 140-148.

12. Jeong, J. W., Lee, Y. C., Jung, S. W. and Lee, K. M. 1994. Flavor components of citron juice as affected by the extraction method. Korean J Food Sci Technol 26, 709-712.

13. Jimenez-Escrig, A. and Cambrodon, I. G. 1999. Nutritional evaluation and physiological effects of edible seaweeds. Arch Latinoam Nutr 49, 114-120.

14. Joung, E. Y. and Lee, S. K. 2007. Antioxidant activity and regeneration effect in $\mathrm{HaCat}$ cell by Jeju Island aboriginal Ecklonia cava. J Korean Soc Cosm 13, 1071-1077.

15. Juma, B. F., Yenesew, A., Midiwo, J. O. and Waterman, P. G. 2001. Flavones and phenylpropenoids in the surface exudate of psiadia punctulata. Phytochemistry 57, 571-574.

16. Karawita, R., Siriwardhana, N., Lee, K. W., Heo, M. S., Yeo, I. K., Lee, Y. D. and Jeon, Y. J. 2005. Reactive oxygen species scavenging, metal chelatin, reducing power and lipid peroxidation inhibition properties of different solvent fractions from Hizikia fusiformis. Eur Food Res Technol 220, 363-371.
17. Kim, H. K., Kim, Y. E., Do, J. R., Lee, Y. C. and Lee, B. Y. 1995. Antioxidative activity and physiological activity of some Korean medicinal plants. Korean J Food Sci Technol 27, 80-85.

18. Kang, K., Park, Y., Hwang, H. J., Kim, S. H., Lee, J. G. and Shin, H. C. 2003. Antioxidative properties of brown algae polyphenolics and their perspectives as chemopreventive agents against vascular risk factors. Arch Pharm Res 26, 286-293.

19. Koing, G. M., Kehraus, S., Seibert, S. F., Abdel-Lateff, A. and Muller, D. 2005. Natural products from marine organism and their associated microbes. Chem Biochem 7, 229-238.

20. Larson, R. A. 1988. The antioxidants of higher plants. Phytochemistry 27, 969-978.

21. Lee, K. D., Chang, H. K. and Kim, H. K. 1997. Antioxidative and nitrite scavenging activities of edible mushrooms. Korean J Food Sci Technol 29, 432-436.

22. Lee, S. K. 1997. Evaluation of cancer chemopreventive activity mediated by antioxidants and modulators of tumor promotion. Ph. D. Thesis, Illinois university, Chicago, USA.

23. Lim, S. B., Kim, S. H., Ko Y. H. and Oh, C. K. 1995. Extraction yields of Hizikia fusiforme and Aloe vera Linne by supercritical carbon dioxide and antimicrobial activity of their extracts. Korean J Food Sci Technol 27, 68-73.

24. Lim, S. N., Cheung, P., Ooi, V. and Ang, P. 2002. Evaluation of antioxidative activity of extracts from a brown seaweed, Sargassum siliquastrum J Agric Food Chem 50, 3862-3866.

25. Matthaus, B. 2002. Antioxidant activity of extracts obtained from residues of different oilseeds. J Agric Food Chem 50, 3444-3452.

26. Miller, H. E. 1971. Simplified method for the evaluation of antioxidants. J Am Oil Chem Soc 48, 91.

27. Moon, B. H., Lee, Y. S., Shin, C. S. and Lim, Y, H. Y. 2005. Complete Assignments of the ${ }^{1} \mathrm{H}$ and ${ }^{13} \mathrm{C}$ NMR Data of Flavone Derivatives. Bull Korean Chem Soc 26, 603-608.

28. Obata, T. and Yamanaka, Y. 1996. Effect of iron (II) on the generation of hydroxyl free radicals in rat mycocardium. Biochem Pharmacol 51, 1411-1413.

29. Owen, T. A., Aronow, M. and Shahoub, V. 1990. Progressive development of the rat osteoblast phenotype in vitro: relationships in expression of genes associated with osteoblast proliferation and differentiation during formation of the bone extracellular matrix. J Cell Physiol 143, 420-430.

30. Oyaizu, M. 1985. Studies on products of browning reaction prepared from glucoseamine. Jpn J Nutr 44, 307-314.

31. Park, J. C. and Choi, J. W. 1996. Screenig of marine natural products on inhibitory effect of the formation of lipid peroxidation. Korean J Pharmacogn 27, 117-122.

32. Park, K. E., Jang, M. S., Lim, C. W., Kim, Y. K., Seo, Y. G. and Park, H. Y. 2005. Anti-oxidant activity on ethanol extract from boiledwater of Hizikia fusiformis. J Korean $S o c$ Appl Biol Chem 48, 435-439.

33. Re, R., Pellegrini, N., Pannala, A., Yang, M. and Rice-Evans, C. 1999. Antioxidant activity applying an improved ABTs radical cation decolorization assay. Free Radical Biol Med 26, 1231-1237. 
34. Yan, X., Nagata, T. and Fan, X. 1998. Antioxidative activities in some common seaweeds. Plant Foods Hum Nutr 52, 253-262.

35. Zhang, Q., Li, N., Zhou, G., Lu, X., Xu, Z. and Li, Z. 2003.
In vivo antioxidant activity of polysaccharide fraction from Porphyra haitanesis (Rhodephta) in aging mice. Pharmacol Res 48, 151-155.

\section{초록 : 톳(Hizikia fusiformis)에서부터 분리된 유기용매 분획물의 항산화활성}

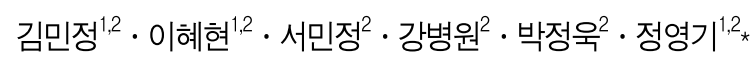

(동아대학교 ${ }^{1}$ 생명공학과, ${ }^{2}$ Medi-Farm 산업화 연구사업단)

Hizikia fusiformis을 $80 \% \mathrm{EtOH}$ 추출물을 용매의 극성에 따라 n-hexane, ethyl acetate, $n-\mathrm{BuOH}$, Aqueous $n$-BuOH fraction으로 순차적으로 분리하였다. 분리된 4 개의 분획물 중에 항산화 활성이 높은 $n-\mathrm{BuOH}$ 분획물을 reserve-phase column chromatography를 실시하여 분리된 3 개의 $\mathrm{BA}, \mathrm{BB}, \mathrm{BC}$ 분획물에 대한 항산화 활성을 검토하였다. 가장 항산화 능이 높은 $\mathrm{BB}$ 분획물은 모든 실험에서 농도의존적으로 활성이 증가하는데, 시료의 농도가 $1.0 \mathrm{mg} / \mathrm{ml}$ 일때 $\mathrm{DPPH} \mathrm{radi}-$ cal scavenging activity와 Reducing power activity는 $45 \pm 0.14 \%, 1.34 \pm 0.23$ 로 가장 높게 나타난다. $\beta$-carotene-linoleic acid activity와 Hydrogen peroxide scavenging activity도 $76 \pm 0.12 \%$ 와 $82 \pm 0.06 \%$ 로 가장 높았으며, ABTS radical scav-

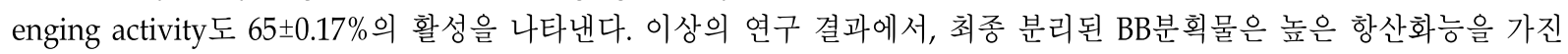
물질을 함유하고 있을 것으로 예상되며, 이는 앞으로 새로운 천연 기능성 식품으로서의 이용 가능성을 시사하고 있다. 